\title{
Cebuano Language
}

National Cancer Institute

\section{Source}

National Cancer Institute. Cebuano Language. NCI Thesaurus. Code C153874.

An Austronesian language spoken in the Philippines mainly in Central Visayas, western parts of Eastern Visayas, and most parts of Mindanao. 